\title{
CORRIGENDUM
}

Genes \& Development 32: 645-657 (2018)

\section{Corrigendum: Maf links Neuregulin1 signaling to cholesterol synthesis in myelinating Schwann cells}

Minchul Kim, Hagen Wende, Jan Walcher, Johannes Kühnemund, Cyril Cheret, Stefan Kempa, Erik McShane, Matthias Selbach, Gary R. Lewis, and Carmen Birchmeier

In the author list of the above-mentioned article, the author name Küehnemund was spelled incorrectly. The correct spelling is Kühnemund and has been updated in the article online.

The authors apologize for this error.

doi: $10.1101 / \operatorname{gad} .318477 .118$ 


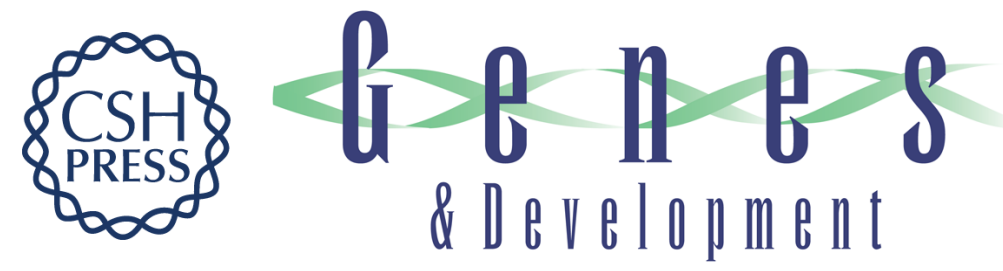

\section{Corrigendum: Maf links Neuregulin1 signaling to cholesterol synthesis in myelinating Schwann cells}

Minchul Kim, Hagen Wende, Jan Walcher, et al.

Genes Dev. 2018, 32:

Access the most recent version at doi:10.1101/gad.318477.118
Related Content Maf links Neuregulin1 signaling to cholesterol synthesis in myelinating Schwann cells
Minchul Kim, Hagen Wende, Jan Walcher, et al.
Genes Dev. May , 2018 32: 645-657

\section{License}

Email Alerting Receive free email alerts when new articles cite this article - sign up in the box at the top Service right corner of the article or click here.

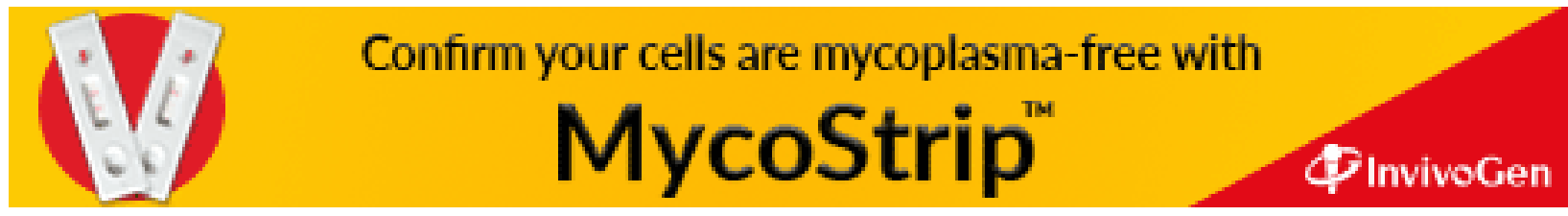

